\title{
THE EFFICACY OF Psidium guajava Linn LEAF EXTRACTS FROM SELANGOR REGION AGAINST GRAM-POSITIVE AND GRAM-NEGATIVE BACTERIA
}

\author{
S. Zuhaira ${ }^{1}$, Noorhaniz Mohd Nizam ${ }^{1}$, P.M. Ridzuan ${ }^{2}$ \\ ${ }^{1}$ Management \& Science University, Department of Medical Sciences, ${ }^{2}$ Management \& Science University, Department \\ of Pre-Clinical, International Medical School, Shah Alam, Selangor, Malaysia
}

\section{ABSTRACT}

\begin{abstract}
Antibiotic is a type of medication that helps in fighting bacterial infection. Treating bacterial infections in clinical setting become more complicated and costly due to drug resistance. This study was conducted to determine the antibacterial potential of Psidium guajava Linn leaf extracts against Gram-positive and Gram-negative bacteria. P. guajava Linn leaf was obtained from Research Orchards at University Putra Malaysia (UPM). Leaves were extracted using three types of extracts; hot, cold and methanol extract. Freeze dried was used in this study and temperature was set at $-104^{\circ} \mathrm{C}$ for 24 hours. Antibacterial testing was determined using disc diffusion and well diffusion method. Antibacterial activity was evaluated by measuring the inhibitory zone of the tested bacteria. Phytochemical analysis was conducted by adding few drop of diluted $\mathrm{NaOH}$ (Sodium Hydroxide) solution to detect the active flavanoid from leaves extract. Antimicrobial activity showed all extracts were effective against Gram-positive and Gram-negative bacteria. Phytochemical analysis of P. guajava Linn leaf extracts showed the methanol extract indicating the presence of tannins, phenols, flavonoids, terpenoids, glycosides and saponins. Results showed that P. guajava Linn leaf was effective against Grampositive and Gram-negative bacteria, and pythochemical analysis also exhibited a few active compounds that were determined. P. guajava Linn leaf had potential natural product that may be used for further analysis in the future research.
\end{abstract}

Keywords: Psidium guajava Linn leaf; antibacterial; pytochemical

\section{ABSTRAK}

Antibiotik adalah jenis obat yang membantu melawan infeksi bakteri. Mengobati infeksi bakteri dalam pengaturan klinis menjadi lebih rumit dan mahal karena adanya resistensi obat. Penelitian ini dilakukan untuk mengetahui potensi antibakteri ekstrak daun Psidium guajava Linn terhadap bakteri Gram-positif dan Gram-negatif. Daun P. guajava Linn diperoleh dari Research Orchards di University Putra Malaysia (UPM). Daun diekstraksi menggunakan tiga jenis ekstrak; ekstrak panas, dingin dan metanol. Bekukan kering digunakan dalam penelitian ini dan suhu ditetapkan pada $-104^{\circ} \mathrm{C}$ selama 24 jam. Pengujian antibakteri ditentukan menggunakan metode difusi cakram dan difusi sumur. Aktivitas antibakteri dievaluasi dengan mengukur zona penghambatan bakteri yang diuji. Analisis fitokimia dilakukan dengan menambahkan beberapa tetes larutan NaOH (Sodium Hydroxide) yang diencerkan untuk mendeteksi flavanoid aktif dari ekstrak daun. Aktivitas antimikroba menunjukkan semua ekstrak efektif terhadap bakteri Grampositif dan Gram-negatif. Analisis fitokimia ekstrak daun P. guajava Linn menunjukkan ekstrak metanol yang menunjukkan adanya tanin, fenol, flavonoid, terpenoid, glikosida dan saponin. Hasil penelitian menunjukkan daun P. guajava Linn efektif terhadap bakteri Gram-positif dan Gram-negatif, dan analisis pythochemical juga menunjukkan beberapa senyawa aktif yang ditentukan. Daun P. guajava Linn memiliki potensi produk alami yang dapat digunakan untuk analisis lebih lanjut dalam penelitian selanjutnya.

Kata kunci: Daun Psidium guajava Linn; antibakteri; fitokimia

Correspondence: P.M. Ridzuan, Department of Pre-Clinical, International Medical School, Management and Science University, University Drive, Off Persiaran Olahraga, Seksyen 13, 40100 Shah Alam, Selangor, Malaysia.

Phone: 013-4748695. E-mail: pm_ridzuan@msu.edu.my/drpmridzuan@gmail.com

pISSN:2355-8393 • eISSN: 2599-056x • doi: http://dx.doi.org/10.20473/fmi.v54i3.10004

- Fol Med Indones. 2018;54:294-300 • Received 28 Aug $2017 \bullet$ Accepted 1 Feb 2018

- Open access under CC-BY-NC-SA license • Available at https://e-journal.unair.ac.id/FMI/

\section{INTRODUCTION}

Antibiotic is a type of medication that helps in fighting bacterial infection. However, nowadays, treating bacterial infection in clinical setting become more complicated and costly due to drug resistance
(Farnsworth 1993). Even though pharmaceutical industries have produced a huge number of new antibiotics, drug resistance is increasing steadily by the year. Drug resistance happens due to misused of antibiotic, and bacteria has ability to mutate their genetic material (Cohen 1992). The development of 
resistance in bacteria is one of the mechanisms of natural adaptation to the presence of antimicrobial agents that inhibits susceptible organisms and selects the resistance ones (Levy \& Marshall 2014). The global emergence of multi-drug resistant bacteria strain is increasingly limiting the effectiveness of current drugs and significantly causing treatment failure of infections (Hancock 2005).

Hence, new antibiotic is needed to be discovered to overcome this issue, and research on efficacy of natural product as antimicrobial agent of one of potential alternative antibiotic that can be used as a regime compliance in clinical setting is required. When infections become resistant to first choice of first line antimicrobials, treatment has to be switched to second or third-line drugs, which are always expensive (WHO 2002). Facing with such challenges, alternative challenges need to be developed to search for new antimicrobial compounds.

Active compound derived from natural sources plays a significant role in the prevention and treatment of human diseases. Plants are rich in wide variety of active compound, such as tannins, terpenoids, alkaloids, flavonoids and glycosides, which have been found in vitro to have antimicrobial properties. P. guajava Linn is one of the plants acclaimed to exhibit antibacterial activity (Gnan 1999).

P. guajava Linn, also known as guava, belongs to the family of Myrtaceae which is widely distribute in tropical and warm temperature regions of the world. $P$. guajava Linn is rich in antimicrobial constituents (Wilson 2001). P. guajava Linn is a phytotherapic plant that widely used in folk medicine to treat and manage various diseasesz such as malaria, gastroenteritis, vomiting, diarrhea, dysentery, wounds, ulcers, toothache, coughs, sore throat and gingivitis (Abdelrahim 2002). Besides, this plant is also used for diabetes, hypertension and obesity (Abdelrahim 2002). Therefore, the objective of this study was to determine the efficacy of $P$. guajava Linn leaf extract against selected Gram-positive and Gram-negative bacteria.

\section{MATERIALS AND METHODS}

\section{Plant collection}

P. guajava Linn leaves was collected from University Research Orchards at University Putra Malaysia (UPM). The leaves were then washed with distilled water to remove debris. Then, leaves were dried in oven at $40^{\circ} \mathrm{C}$ for 24 hours until the leaves were completely dry. After cleaning and drying process was done, the dried leaves were ground into powder using an electrical commercial Panasonic blender and stored in chiller until further use.

\section{Extraction process}

Cold aqueous extraction process

A total of $20 \mathrm{~g}$ of dried leaf powder was weighed and soaked in $100 \mathrm{~mL}$ of cold distilled water in a sterile 250 $\mathrm{mL}$ conical flask at room temperature for 24 hours. Then, the sample was filtered using sterile Whatman No. 1 filter paper into new sterile $250 \mathrm{~mL}$ conical flask. The extracted sample was evaporated using freeze dryer for 24 hours at the temperature of $-104^{\circ} \mathrm{C}$. The extract powder was obtained and kept in labelled air tight bottle until further use.

\section{Hot extraction aqueous process}

A total of $20 \mathrm{~g}$ of dried leaves powder was soaked in $100 \mathrm{~mL}$ of hot distilled water in a $250 \mathrm{ml}$ conical flask and boiled for 30 minutes before kept at room temperature for 24 hours. The sample was filtered using sterile Whatman No. 1 filter paper into new sterile 250 $\mathrm{mL}$ conical flask. The sample was evaporated using freeze dryer for 24 hours at temperature of $-104^{\circ} \mathrm{C}$. The extract powder obtained was kept in container.

Methanol extraction process

A total of $20 \mathrm{~g}$ of dried leaves powder was weighed and soaked into $100 \mathrm{~mL}$ of methanol in $250 \mathrm{~mL}$ conical flask. Then, the sample was filtered using sterile Whatman No. 1 filter paper. The sample was evaporated using a freeze dryer for 24 hours at the temperature of $104^{\circ} \mathrm{C}$. The extract powder obtained was kept until further use.

\section{Preparation of $\boldsymbol{P}$. guajava extraction and standard antibiotic preparation}

The extract concentrations were prepared by diluting 15 $\mathrm{mg}$ of each type of extract powder with $1 \mathrm{~mL}$ of distilled water to make into $15 \mathrm{mg} / \mathrm{mL}$. Erythromycin $(15 \mu \mathrm{g})$ was used in this study and was purchased from Sigma-Aldrich.

\section{Phytochemical analysis}

Phytochemical analysis to screen and identify the active compounds in the P. guajava Linn leaf were carried out. One $\mathrm{mL}$ of each solvent extract was used for this analysis, exception for the saponin test which was $3 \mathrm{~mL}$ solvent extract was used. 
Test for saponins

Extract was placed in a test tube and shaken vigorously. The formation of stable foam was taken as an indication for the presence of saponins (Brain \& Turner 1975).

Test for phenols and tannins

Extract was mixed with $2 \mathrm{~mL}$ of $2 \%$ solution of $\mathrm{FeCl}_{3}$. A blue-green or black coloration indicated the presence of phenols and tannins (Ciulei 1994).

Test for terpenoids (Salkowski's Test)

Extract was mixed with $2 \mathrm{~mL}$ of chloroform. Then, 2 $\mathrm{mL}$ of concentrated sulfuric acid was added carefully and shaken gently. A reddish-brown coloration of the interphase was formed to show positive results for the presence of terpenoids

Test for flavonoids (Shinoda Test)

Extract was mixed with magnesium ribbon fragments, and concentrated hydrochloric acid was added drop wise. Orange, red, pink, or purple coloration indicates the presence of flavonoids (Sofowora 1993)

\section{Test for glycoside}

Extract was mixed with $2 \mathrm{~mL}$ of glacial acetic acid containing 2 drops of $2 \% \mathrm{FeCl}_{3}$. The mixture was poured into another tube containing $2 \mathrm{~mL}$ of concentrated sulfuric acid. A brown ring at the interphase indicates the presence of glycosides (Sofowora 1993).

\section{Antibacterial activity test}

Test of microorganisms

The organisms were supplied by Microbiology and Parasitology Unit of Management and Science University (MSU). Three Gram-positive bacteria used: (Staphylococcus aureus, Streptococcus Pyogenes, and Bacillus subtilis) and three Gram-negative bacteria: (Eschericia coli, Pseudomonas auruginosa, and Salmonella typhi) were used in this study.

Inoculum preparation

Using inoculation loop, the tested organism was transferred into test tube containing Nutrient Broth until the turbidity of suspension matched the turbidity of the 0.5 McFarland Standard.

Disc diffusion method

Disc diffusion method was used to determine the antimicrobial activities of $P$. guajava extract. Using
Whatman filter paper No. 1, $0.5 \mathrm{~mm}$ disc were prepared using paper puncher before autoclave at the temperature of $121^{\circ} \mathrm{C}$ for 15 minutes. $15 \mu \mathrm{L}(15 \mathrm{mg} / \mathrm{mL})$ of solvent extracts (cold extract, hot extract and methanol extract of P. guajava Linn leaves) were loaded. Furthermore, discs containing $P$. guajava extract was placed directly onto the surface of Muller Hinton agar (MHA) plates which had been smeared with the tested organisms. The culture media were then incubated in incubator at temperature of $37^{\circ} \mathrm{C}$ for 24 hours. Inhibition zone was observed and measured after incubation period. All experiments were performed in triplicates to ensure reproducibility.

Well diffusion method

Muller Hinton agar (MHA) plates were prepared in advanced with different cultures and few wells with 5 $\mathrm{mm}$ diameter, cut using a sterile cord borer. The wells were filled with $5 \mu \mathrm{L}$ extract solvent (cold extract, hot extract and methanol extract of $P$. guajava Linn leaves) separately and incubated at $37^{\circ} \mathrm{C}$ for 24 hours. Inhibition zone was observed and measured after incubation period.

\section{Statistical analysis}

The inhibition zone were calculated as mean \pm SD $(n=3)$. The statistical significance between different types of $P$. guajava Linn leaf extracts against different types of bacteria was compared with the positive control and ascertained using Excel Student's two-tailed t-test for non-paired observations.

\section{RESULTS}

\section{Phytochemical analysis}

Methanol extract of $P$. guajava Linn leaf showed the presence of phenol, tannin, glycoside, flavonoid and terpenoid, but the absence of saponin. Both hot and cold extracts of P. guajava Linn leaf showed the presence of all the phytochemicals which are saponin, phenol, tannin, glycoside, flavonoid and terpenoid (Table 1).

\section{Antibacterial activity test}

Disc diffusion method

In the disc diffusion antibiotic sensitivity test, a thin film of antibiotic is applied on a plate subjected to various bacteria. The zone of inhibition is a clear circular area around the spot of the antibiotic in which the bacteria colonies do not grow. 
Table 1. Phytochemical constituents of Psidium guajava Linn leaf extracts

\begin{tabular}{lcccccc}
\hline \multicolumn{1}{c}{ Extracts } & Saponin & Phenol & Tannin & Glycoside & Flavonoid & Terpenoid \\
\hline Cold aqueous & + & + & + & + & + & + \\
Hot aqueous & + & + & + & + & + & + \\
Methanol & - & + & + & + & + & + \\
\hline Note: + Presence of constituents (Positive) & & & & \\
-: Absence of constituents (Negative) & & &
\end{tabular}

Table 2. Correlation between different types of $P$. guajava Linn leaf extracts and zone of inhibition against different types of bacteria using disc diffusion method

\begin{tabular}{lcccc}
\hline \multirow{2}{*}{ Bacteria } & $\begin{array}{c}\text { Cold } \\
\text { aqueous } \\
\text { extract }\end{array}$ & $\begin{array}{c}\text { Hot } \\
\text { aqueous } \\
\text { extract }\end{array}$ & $\begin{array}{c}\text { Methanol } \\
\text { extract }\end{array}$ & $\begin{array}{c}\text { Positive } \\
\text { control } \\
\text { (Erythromycin) }\end{array}$ \\
\hline $\begin{array}{c}\text { Gram-positive } \\
\text { bacteria } \\
\text { Staphylococcus } \\
\text { aureus }\end{array}$ & $6.3 \pm 0.6$ & $8.3 \pm 1.5$ & $10.7 \pm 2.1$ & $30.7 \pm 3.1$ \\
$\begin{array}{c}\text { Streptococcus } \\
\text { pyogenes }\end{array}$ & $10.3 \pm 1.2$ & $12.0 \pm 2.0$ & $11.0 \pm 4.0$ & $23.3 \pm 3.1$ \\
Bacillus subtilis & $7.3 \pm 0.6$ & $6.8 \pm 0.3$ & $8.3 \pm 1.5$ & $29.3 \pm 2.5$ \\
\hline $\begin{array}{c}\text { Gram-negative } \\
\text { bacteria }\end{array}$ & & & & \\
$\begin{array}{c}\text { Escherichia coli } \\
\text { Pseudomonas }\end{array}$ & $9.3 \pm 2.1$ & $9.0 \pm 1.0$ & $12.7 \pm 1.5$ & $10.7 \pm 2.1$ \\
$\begin{array}{c}\text { aeruginosa } \\
\text { Salmonella typhi }\end{array}$ & $11.7 \pm 0.6$ & $13.0 \pm 2.6$ & $11.3 \pm 2.1$ & $10.7 \pm 1.5$ \\
\hline
\end{tabular}

The zone of inhibition were used to measure the susceptibility of the bacteria towards the antibiotic. The zone of inhibition was measured using a ruler. The diameter of the zone of inhibition will determine the effectiveness of the antibiotic. The larger the diameter, the higher will be the sensitivity of the bacterium to the antibiotic.

It can be seen that $P$. guajava Linn leaf extract for all types, cold aqueous extract, hot aqueous extract and methanol extract, were more sensitive on Gramnegative bacteria; Escherichia coli, Pseudomonas aeruginosa and Salmonellas typhi. This was due to larger diameter of zone of inhibition as compared on Gram-positive bacteria.

\section{Well diffusion method}

In the disk diffusion antibiotic sensitivity test, a thin film of antibiotic is applied on a plate subjected to various bacteria. The zone of inhibition is a clear circular area around the spot of the antibiotic in which the bacteria colonies do not grow. The zone of inhibition are used to measure the susceptibility of the bacteria towards the antibiotic. The zone of inhibition is measured using a ruler. The diameter of the zone of inhibition will determine the effectiveness of the antibiotic. The larger the diameter, the higher will be the sensitivity of the bacterium to the antibiotic.

It can be seen that $P$. guajava Linn leaf extract for all types, cold aqueous extract, hot aqueous extract and methanol extract, were more sensitive on Gram-positive bacteria; Staphylococus aureus, Streptococcus pyogenes and Bacillus subtilis. This waa due to larger diameter of zone of inhibition as compared on Gram-negative bacteria.

\section{DISCUSSION}

\section{Phytochemical analysis}

The antibacterial properties of remedial plants were due to presence of active compounds, such as phenol tannin, glycoside, flavonoid, terpenoid and saponin. Based on Table 4.1, the methanol extract of P. guajava Linn leaf shows the presence of phenol, tannin, glycoside, flavonoid and terpenoid, but the absence of saponin. Both hot and cold extracts of $P$. guajava Linn leaf showed the presence of all phytochemicals, which are saponin, phenol, tannin, glycoside, flavonoid and terpenoid. From this scrutiny, hot and cold extract was found to have more fractions compared to methanol extract. 
Table 3. Correlation between different types of $P$. guajava Linn leaf extracts and zone of inhibition against different types of bacteria using well diffusion method

\begin{tabular}{lcccc}
\hline \multirow{2}{*}{ Bacteria } & $\begin{array}{c}\text { Cold } \\
\text { aqueous } \\
\text { extract }\end{array}$ & $\begin{array}{c}\text { Zot } \\
\text { aqueous } \\
\text { extract }\end{array}$ & $\begin{array}{c}\text { Methanol } \\
\text { extract }\end{array}$ & $\begin{array}{c}\text { Positive control } \\
\text { (Erythromycin } \\
15 \mu \mathrm{g} / \mathrm{disc})\end{array}$ \\
\hline $\begin{array}{c}\text { Gram-positive bacteria } \\
\text { Staphylococcus aureus }\end{array}$ & $12.7 \pm 4.2$ & $15.0 \pm 2.0$ & $17.3 \pm 3.1$ & $7.7 \pm 0.6$ \\
$\begin{array}{c}\text { Streptococcus } \\
\text { pyogenes }\end{array}$ & $17.3 \pm 0.6$ & $17.0 \pm 3.6$ & $16.0 \pm 3.6$ & $20.0 \pm 2.0$ \\
Bacillus subtilis & $10.7 \pm 2.1$ & $11.5 \pm 2.3$ & $14.3 \pm 1.5$ & $16.0 \pm 1.0$ \\
\hline $\begin{array}{c}\text { Gram-negative bacteria } \\
\text { Escherichia coli }\end{array}$ & $13.7 \pm 0.6$ & $16.0 \pm 0.0$ & $14.7 \pm 0.6$ & $8.3 \pm 1.5$ \\
$\begin{array}{c}\text { Pseudomonas } \\
\text { aeruginosa }\end{array}$ & $13.0 \pm 4.4$ & $13.3 \pm 2.5$ & $14.0 \pm 1.0$ & $11.3 \pm 1.5$ \\
Salmonella typhi & $16.7 \pm 4.2$ & $16.0 \pm 2.6$ & $15.0 \pm 3.0$ & $7.7 \pm 1.2$ \\
\hline
\end{tabular}

The presence of phytochemical compounds in $P$. guajava Linn leaf extracts was reported to be responsible for antimicrobial activity. Flavonoid and tannin are well documented for antimicrobial activity. Tannin is a polyphenolic compound that bind to rich protein that interferes antimicrobial activity. Flavonoid is a hydroxylated poyphenolic compound known to be produced by plants to response to microbial infections that found to have antimicrobial activity against an array of microorganisms in vitro (Dixon et al 1983). Terpenoid mainly used as aromatic qualities have found to be potential agent against inhibiting bacteria (Tsuchiya et al 1996). Therefore, the phytochemical analysis revealed that all three types of P. gujava Linn leaf extracts had chemical compounds that been found to possess antibacterial activities.

\section{Antibacterial activity test}

Result of this study revealed antibacterial activity test using both disc and well diffusion indicated that the crude solvent extracts prepared from the leaves of $P$. guajava Linn; cold extract, hot extract and methanol extract showed inhibitory activity against all tested bacteria. Gram-positive bacteria (Bacillus subtilis, Stretococus pyogenes and Staphylococcus aureus) and Gram-negative bacteria (Eschericia coli, Pseudomonas aeruginosa and Salmonella typhi) were susceptible to the three extracts. Methanol extract showed slightly higher antibacterial activity than cold and hot extract.

The resistance of Gram-negative bacteria could be attributed to its cell wall structure. Gram-negative bacteria have an effective permeability barrier, comprised of a thin lipopolysaccharide exterior membrane, which could restrict the penetration of the extruding the plant extract. It had been reported earlier that Gram-negative bacteria are usually more resistant to the plant-origin antimicrobials and even show no effect, compared to Gram-positive bacteria. Grampositive bacteria have a mesh-like peptidoglycan layer which is more accessible to permeation by the extracts. Therefore, P. guajava Linn extracts possess bioactive compounds that can be used as antibacterial agent in curing bacterial infection.

Phenolic contents and flavonoid contents present in the plant body mainly give the idea of its medicinal importance. These are considered the index of the antioxidant and free radical scavenging strength of the plants, as these components are involved in deleting, neutralizing or scavenging free radicals (Duh et al 1999, Pietta 2000) due to the presence of conjugated ring systems and carboxylic groups. These functional group in phenolic and flavonoid compounds also involve strongly to inhibit lipid peroxidation (Rice-Evans et al 1995).

The knowledge of medicinal property of plants has been aggregated throughout many hundreds of years. The local inhabitant has acquired rich traditional knowledge on the utilization of many plants or plant parts for treatment of regular disease. Therapeutic plants give accessible and socially relevant sources of essential health care. The cu res in view of these plants regularly have minimized side effect. The bioactive substances in plants are created as secondary metabolites, which may be development stage as well as organ and tissue specific. Whereas, plant leaf, stem and root separates have been broadly assessed for bioactive mixes, screening of plant petal has not been broad. Secondary metabolites which belong to polyketide and nonribosomal peptide families constitute a major class of natural products with different biological functions and they have an assortment of pharmaceutically critical properties. 
The antibacterial activity test using $P$. guajava Linn leaf extract was completed. The extraction demonstrated an antibacterial activity against the human pathogens; $S$. aureus, S. pyogenes, E. coli, B. subtilis, P. aeruginosa and S. typhi. All of the P. guajava Linn leaf extracts had demonstrated the activity. Examinations were completed on plant materials as alternative sources of antibacterial agents. It has turned out to be more common in the recent years because of an expanded rate of development of antibiotic resistance microorganism.

In the present investigation, corolla extracts from $P$. guajava Linn leaf were screened for antibacterial activity against human pathogenic bacterial strains. In general, Gram-negative bacteria have been found to be more resistant than Gram-positive bacteria. So, these results were in contrast from the previous investigation (Ruban \& Gajalakshmi 2012). From the previous investigation (Ruban \& Gajalakshmi 2012), it was reported that the cold extractions of the P. guajava Linn leaf inhibited greater zone of inhibition than hot extraction. However, in the present work it can be stated that hot and methanol extracts were more potent than cold extract.

The restraint of bacterial development by the extracts of P. guajava Linn leaf could be because of the nearness of some active chemical constituents in the extracts. These active compounds may act alone or in blend to inhibit bacterial development. The $P$. guajava Linn leaf extracts containing various natural components including flavonoids, tannins, alkaloids, terpenoids, all of which are known to have antibacterial effects. Leaf extracts contain phenolic compounds, such as tannins, that are great antimicrobial operator. In this way it might be abridged that the class of natural compounds must exhibit the antibacterial action. The metabolites have been showed to be responsible of various therapeutic activities of medicinal plants. Flavonoids particularly are known to be effective antimicrobial agent against a wide cluster of microorganisms. The activity is ascribed to their capacity to complex with extra cellular and soluble proteins and with bacterial cell wall. There are a few reports published on antibacterial activity of different herbal extracts. It bolsters the earlier investigations that the tannins isolated from the $P$. guajava Linn leaf have remarkable antibacterial activity against microorganisms and may expect pharmacological significance. Numerous antimicrobial screening studies utilize a generally little number of microorganisms for testing. It is possible that these plant materials contain antibacterial activity against pathogenic microscopic organisms other than those tried in this research. Likewise, the lack of activity might be a direct result of degradation of active chemicals amid the drying procedure, the extraction procedure.
The concentrates have demonstrated antibacterial activity against these pathogens. E. coli are common member from the normal flora of digestive organ. It is predominant facultative life organism in the gastrointestinal tract and colonizes the tract within hours or few days. It is in responsible of bringing about inflammatory bowel which is described by fast onset of watery non-bloody liquid. S. aureus is a facultative anaerobe that develops by aerobic respiration or by fermentation which yields lactic acid. These are pathogenic to people. They cause a wild scope of superlative contamination and in addition nourishment harming and poisonous stun disorder. S. typhi incorporates an extensive number of pathogens of people and also warm-blooded creatures. These are pathogenic when procured by oral route. Comprehensively they may bring about enteric fever, septicaemia and enteritis. The enteric fever and septicaemia are brought about by thousands of Salmonella. Subsequently the plant concentrates can be utilized as a critical antibiotic to cure previously mentioned disease or disorders brought about by the distinctive strains of microscopic organisms. The present studies conclude that these extracts could inhibit the growth of human pathogens. The outcomes are empowering yet precise assessment is totally essential before being situate in practice as well as the most active extracts can be subjected to isolation of the therapeutic antimicrobials and undergo secondary pharmacological evaluation.

However, further pharmalogical evaluations, toxicological studies and possible identification and standardization of the therapeutic antibacterial agent from $P$. guajava Linn leaf need to be carried out.

\section{CONCLUSION}

As a conclusion, the results obtained from this study showed that $P$. guajava Linn leaf had antibacterial effect on common microorganisms that attack human; Grampositive bacteria ( $S$. aureus, S. pyogenes, and B. subtilis) and Gram-negative bacteria (E. coli, P. aeruginosa, and $S$. typhi). Hence, it can be concluded that $P$. guajava Linn leaf, which has been used as traditional medicine since time of immemorial, demonstrated antibacterial potential and possessed the capabilities of being a good candidate for a new natural agent against infections and diseases caused by microorganisms. P. guajava Linn leaf may be a good source for commercial production of antibacterial drugs which will be natural and without side effects. In addition to that, all types of $P$. guajava Linn extracts were significant $(\mathrm{p}<0.05)$ on all types of bacteria. Thus, alternate hypothesis were accepted. In this regard, further studies need to be carried out to 
explore more on $P$. guajava Linn leaf for its potential in preventing and treating diseases, so it could be used for prevention and as an adjuvant in the numerous diseases.

\section{ACKNOWLEDGMENTS}

I would like to thank all IMS staffs, Madam Zuhaira Sahid for her patience in painstakingly going through all my drafts and giving advice, support, valuable criticisms, suggestion and most of all her encouragement throughout the entire research study process. I also would like to thank my friends, Fara Izwarina and Farhana Aliasa for their help and guidance throughout this study.

\section{REFERENCES}

Abdelrahim SI, Almagboul AZ, Omer ME, Elegami A (2002). Antimicrobial activity of Psidium guajava Linn. Fitoterapia 73, 713-715

Brain KR, Turner TD (1975). The practical evaluation of phytopharmaceuticals Wright-scientechnica Bristol, 4-9, 60, 76-79

Ciulei I (1994). Methodology for the analysis of vegetable drugs, chemical industries branch. Division of Industrial operations. Romania, UNID O, p 21-97

Cohen ML (1992). Epidemiology of drug resistance: Implications for a post-antimicrobial era. New York, Science , p 257

Dixon RA, Dey PM, Lamb CJ (1983). Phytoalexins: Enzymology and molecular biology. Advances in Enzymology and Related Areas of Molecular Biology $55,1-136$

Duh PD, Tu YY, Yen GC (1999). Antioxidant Activity of Water Extract of Harng Jyur (Chrysanthemum morifolium Ramat). LWT - Food Science and Technology 32, 269-277

Farnsworth NR (1993). Ethno pharmacology and future drug development: The North American experience. J Ethnopharmacol 38, 145-52

Gnan SO, Demello MT (1999). Inhibition of Staphylococcus aureus by aqueous goiba extracts. J. Ethnopharm 68, 103-108

Hancock EW (2005). Mechanisms of action of newer antibiotics for Gram-positive pathogens. Lancet Infect. Dis 5, 209-218

Levy SB, Marshall B (2004). Antibacterial resistance worldwide: causes, challenges and responses. Nature Medicine 10, S122-S129

Pietta PG (2000). Flavonoids as antioxidants. J Nat Prod 63, 1035-42

Rice-evans CA, Miller NJ, Bolwell PG, Bramley PM, Pridham JB (1995) The relative antioxidant activities of plant-derived polyphenolic flavonoids. Free Radical Research 22, 375-383

Ruban P, Gajalakshmi K (2012). In vitro antibacterial activity of Hibiscus rosa-sinensis flower extract against human pathogens. Asian Pac J Trop Biomed 2, 399-403

Sofowora AA (1993). Medicinal plants and Traditional medicines in Africa 2nd edition. Ibadan, Spectrum Books Ltd, p 81-85

Tsuchiya H, Sato M, Miyazaki T (1996) Comparative study on the antibacterial activity of phytochemical flavanones against methicillin-resistant Staphylococcus aureus. Journal of Ethnopharmacology 50, 27-34

Wilson GP (2001), Myrtaceae revised: A reassessment of infrafamilial groups. American Journal of Botany 88, 2013-2025

World Health Organization (WHO) (2002). Antimicrobial resistance. Bristol, Fact sheet No. 194m Wright Scientechiea, p 57-58 